\title{
OBSERVATIONS ON ROUTINE MEDICAL EXAMINATIONS OF UNIVERSITY ENTRANTS IN NORTHERN IRELAND
}

\author{
BY \\ W. JOHNSTON, E. A. CHEESEMAN, AND J. D. MERRETT \\ Departments of Student Health and of Social and Preventive Medicine, Queen's University of Belfast
}

\section{INTRODUCTION}

The first complete academic year of the present student health service at the Queen's University of Belfast was 1949-50. Since that year every undergraduate entrant has been medically examined during his or her first year. At the end of each academic year the medical officer makes a formal report to a University sub-committee and includes statistical information about these routine examinations. This information is mainly limited to the detection and treatment of defects. In this paper we report other aspects of the 2,716 examinations carried out during the first 5 years of the service.

The data relate to age, sex, weight, height, sitting height, chest girth, chest expansion, pulse rate, systolic and diastolic blood pressures, vital capacity, visual acuity, colour vision, and hearing. All but ten of the 2,716 students were examined by the same physician (W.J.), assisted throughout by the same nursing sister, following the procedure and methods of measurement and assessment described in the next section. In subsequent sections, averages and standard deviations of quantitative measurements and distributions of qualitative assessments are analysed, with particular reference to age and sex variations. Some comparisons are made with other contemporary data, but these are few because of the variety of methods and criteria in published work.

In this report the word "significant" describes an estimate which, in relation to its standard error, is so large as to be unlikely to occur by chance more than once in twenty trials, i.e. $P<0.05$. Where standard errors are quoted, they follow the " \pm " sign after the estimate to which they refer. It has been convenient to use the analysis of variance technique in many instances and this analysis is given in the Appendix.

\section{Examination Procedure and Methods}

Each student attends for examination by appointment. On arrival the student is interviewed by the sister who starts an examination record. Men then undress, except for trousers, and women remove all outer garments; no shoes are worn. The sister measures weight, height, sitting height, and vital capacity, and tests visual acuity, colour vision, and hearing. The medical officer then makes a clinical examination: this includes measurement of chest girth and chest expansion and concludes with estimation of pulse rate and blood pressure. The sister's work usually takes about 20 to 30 minutes and the physician's about 40 to 60 minutes; thus the blood pressures are normally taken when the student has had at least one hour in the surgery.

The details of methods of measurement and assessment are as follows:

Weight.-Men wear trousers only and women are partially clothed; no shoes are worn. Measurement is made, to the nearest lb., on an Avery beam type machine with loose weights and a sliding scale; the apparatus is checked annually. Weights have been converted to $\mathrm{kg}$.

Height.-No shoes are worn. Measurement is made, to the nearest $\mathrm{cm}$., with a sliding horizontal cursor on a vertical scale. Students stand as erect as possible with feet together, looking straight ahead at eye level.

Sitting Height.-Measurement is made, to the nearest $\mathrm{cm}$., with a sliding horizontal cursor on a vertical scale, which is fixed to the back of a small metal chair with a level seat. Students sit as erect as possible, looking straight ahead at eye level.

Chest Girth.-The chest is uncovered and measurement is made, to the nearest $\mathrm{cm}$., with a tailor's measuring tape. The upper edge of the tape is put at the level of the fourth costo-chondral joint and the lower edges of 
the scapulae, while the student stands erect with chest relaxed.

Chest Expansion.-Two further chest girth measurements are made as before except that, for one, the chest is fully inspired, and for the other, fully expired. Chest expansion is calculated as the difference, to the nearest cm., between these measurements.

Pulse Rate.-This is estimated in beats per minute. Beats are counted for 60 seconds timed with the second hand of a watch. Students lie on their backs on a couch.

Blood Pressure.-Systolic and diastolic pressures are measured, to the nearest $5 \mathrm{~mm}$. $\mathrm{Hg}$, with a Riva Rocci syphgmomanometer, which is periodically checked. Students remain on the couch after pulse rate is taken and are in this position for at least ten minutes before blood pressures are measured; by then they have been in the surgery for at least one hour. Systolic pressure is recorded at the instant when sounds are first heard and diastolic at the instant when sounds abruptly diminish prior to disappearance. The method conforms to the standards of the Cardiac Society of Great Britain and Ireland and the American Heart Association (1939).

Vital Capacity.-Measurement is made, to the nearest 0.1 litres, with a Kendrick vital capacity spirometer. The sister gives a demonstration to each student. Students have one "trial run" and the average of the next three attempts is the vital capacity recorded.

Visual Acuity.-Unaided visual acuity is tested, for each eye separately, using the standard Snellen type and illumination. Each eye is classified as $6 / 6,6 / 9,6 / 12,6 / 18$, $6 / 24,6 / 36$, or $6 / 60$. (The limitations of this test are obvious and it is used to detect gross errors and as an indication of the need for more detailed examination.)
Colour Vision.-This is tested by the Ishihara (1943) method with pseudo-isochromatic plates, but no special illumination is used. Each student is classified as "normal" or "abnormal".

Hearing.-Each ear is tested separately, the untested ear being plugged with cotton wool. The sister, after expiration, whispers at a distance of $20 \mathrm{ft}$. from the student. If the whisper can be heard by each ear, hearing is classified as "normal"; if not, the defect is noted. If any diminution is detected, careful examination of the ear is made by the physician. If temporary causes, such as the presence of cerumen or upper respiratory infection, are observed, appropriate treatment is given and hearing retested after cure and the original results amended as appropriate. Thus in this analysis only permanent abnormality is noted.

\section{Age ANd Sex Distribution}

More than 80 per cent. of the 2,716 students examined were aged 17-19 years, and although there were no significant differences in mean age of entrants between the five academic years (Appendix Serials 1 and 2), the high $\chi^{2}$ values of Table I suggest some such differences in age distribution. These differences were mainly due to the residual intake of ex-service students aged 20 and over in 1949-50, coupled with correspondingly fewer entrants in the youngest age group. The mean age of entry of men $(19 \cdot 3 \mathrm{yrs})$ was significantly higher than that of women (18.6 yrs) (Appendix Serial 3). Only 10.9 per cent. of the women, compared with 20.5 per cent. of the men, were aged 20 and over (Table I).

TABLE I

AGE AND SEX DISTRIBUTION OF ENTRANTS EXAMINED, BY YEAR OF ENTRY

\begin{tabular}{|c|c|c|c|c|c|c|c|c|}
\hline \multirow{2}{*}{ Sex } & \multirow{2}{*}{$\begin{array}{l}\text { Year of } \\
\text { Entry }\end{array}$} & \multicolumn{5}{|c|}{ Age Group (yrs) } & \multicolumn{2}{|c|}{ Age (yrs) } \\
\hline & & $17-$ & $18-$ & 19- & $20+$ & Total & Mean & $\begin{array}{l}\text { Standard } \\
\text { Deviation }\end{array}$ \\
\hline \multirow[t]{2}{*}{ Male } & $\begin{array}{l}1949-50 \\
1950-51 \\
1951-52 \\
1952-53 \\
1953-54\end{array}$ & $\begin{array}{l}51 \\
78 \\
75 \\
62 \\
45\end{array}$ & $\begin{array}{l}174 \\
162 \\
173 \\
182 \\
172\end{array}$ & $\begin{array}{l}85 \\
72 \\
89 \\
73 \\
69\end{array}$ & $\begin{array}{r}114 \\
77 \\
87 \\
71 \\
55\end{array}$ & $\begin{array}{l}424 \\
389 \\
424 \\
388 \\
341\end{array}$ & $\begin{array}{l}19 \cdot 8 \\
19 \cdot 1 \\
19 \cdot 3 \\
19 \cdot 2 \\
19 \cdot 2\end{array}$ & $\begin{array}{l}3 \cdot 9 \\
3 \cdot 3 \\
3 \cdot 5 \\
3 \cdot 5 \\
3 \cdot 7\end{array}$ \\
\hline & Total & $\begin{array}{l}311 \\
(15 \cdot 8)\end{array}$ & $\begin{array}{l}863 \\
(43 \cdot 9)\end{array}$ & $\begin{array}{l}388 \\
(19 \cdot 7)\end{array}$ & $\begin{array}{l}404 \\
(20 \cdot 5)\end{array}$ & $\begin{array}{c}1,966 \\
(100)\end{array}$ & $19 \cdot 3$ & $3 \cdot 6$ \\
\hline Female & $\begin{array}{l}1949-50 \\
1950-51 \\
1951-52 \\
1952-53 \\
1953-54\end{array}$ & $\begin{array}{l}18 \\
29 \\
41 \\
33 \\
35\end{array}$ & $\begin{array}{l}59 \\
78 \\
79 \\
72 \\
96\end{array}$ & $\begin{array}{l}36 \\
22 \\
29 \\
21 \\
20\end{array}$ & $\begin{array}{l}21 \\
22 \\
10 \\
16 \\
13\end{array}$ & $\begin{array}{l}134 \\
151 \\
159 \\
142 \\
164\end{array}$ & $\begin{array}{l}18 \cdot 7 \\
18 \cdot 7 \\
18 \cdot 3 \\
18 \cdot 7 \\
18 \cdot 4\end{array}$ & $\begin{array}{l}1 \cdot 8 \\
2 \cdot 8 \\
1 \cdot 9 \\
3 \cdot 3 \\
2 \cdot 5\end{array}$ \\
\hline - & Total & $\begin{array}{l}156 \\
(20 \cdot 8)\end{array}$ & $\begin{array}{l}384 \\
(51 \cdot 2)\end{array}$ & $\begin{array}{l}128 \\
(17 \cdot 1)\end{array}$ & $\begin{array}{l}82 \\
(10 \cdot 9)\end{array}$ & $\begin{array}{c}750 \\
(100)\end{array}$ & $18 \cdot 6$ & $2 \cdot 5$ \\
\hline
\end{tabular}

Figures in brackets give percentage age distribution for each sex. 
TABLE II

PHYSICAL MEASUREMENTS

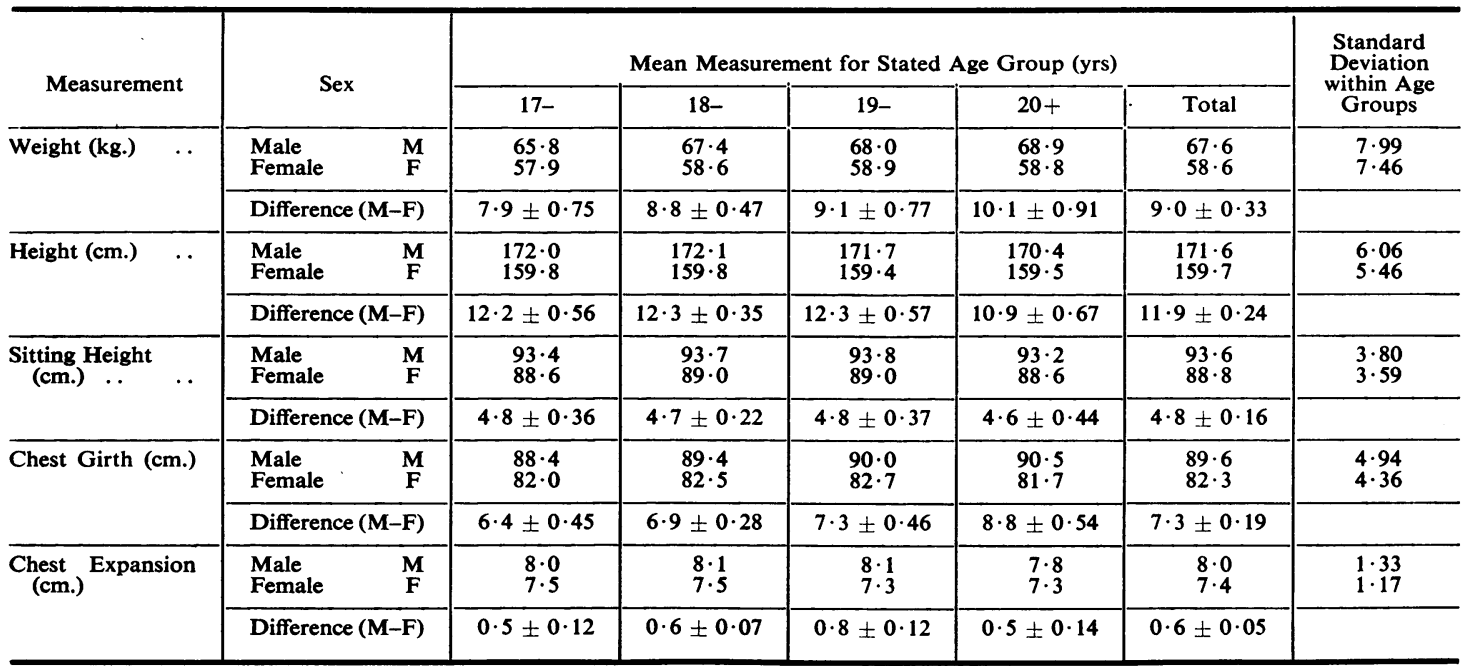

In what follows, the data are presented for each sex and age group separately, but for all five academic years combined. Thus mean measurements and qualitative distributions are based on the numbers in the total rows of Table $\mathrm{I}$. The mean age of men in the oldest age group was $24 \cdot 3 \mathrm{yrs}$; for women it was $23 \cdot 5$ yrs. Because of the heterogeneous nature of this age group, the examination of age variations of each measurement by analysis of variance has been supplemented by correlation coefficients between measurement and exact age.

\section{Physical Measurements}

General.-Table II gives the means of weight, height, sitting height, chest girth, and chest expansion. In each age group the means for men were significantly higher than those for women. Sitting height means were not significantly associated with age (Appendix Serials 8 and 9 and Table III). The means of each of the other four measurements of males differed significantly between age groups (Serials 4, 6, 10 and 12) and, although not significant (Serials 5, 7, 11, and 13), similar age trends occurred among females. These means (Table II) and the correlation coefficients (Table III) suggest, at least for males, that whilst weight and chest girth increased with increasing age even beyond age 20 years, height and chest expansion decreased. However, in all cases, the age effect was slight, and among males, on the assumption of a linear relationship, would amount to average differences, per increase of one year of age, of $+0.31 \pm 0.05 \mathrm{~kg}$. in weight,
$+0.14 \pm 0.03 \mathrm{~cm}$. in chest girth, $-0.18 \pm 0.04$ $\mathrm{cm}$. in height, and $-0.03 \pm 0.01 \mathrm{~cm}$. in chest expansion.

Comparison with Other Series.-Several reports on physical measurements of different population groups, some of which were composed of university students, have been made within the last 10 years. We have been able to obtain results in comparable age groups from the following:

(1) Bailey (1951) gave data on weight and height for about 3,000 Cambridge male freshmen aged 18-22 years for 1948-50. These men, representing about 75 per cent. of all freshmen, were volunteers. They were measured in trousers and without shoes.

(2) Grant and Hitchens (1953) reported weight data

TABLE III

CORRELATION COEFFICIENTS $(r)$ BETWEEN AGE AND VARIOUS MEASUREMENTS

\begin{tabular}{|c|c|c|c|c|}
\hline \multirow{2}{*}{$\begin{array}{l}\text { Correlation between } \\
\text { Age and Stated } \\
\text { Measurement }\end{array}$} & \multicolumn{2}{|c|}{ All Students } & \multicolumn{2}{|c|}{$\begin{array}{c}\text { Students Aged } \\
20+\text { yrs }\end{array}$} \\
\hline & Males & Females & Males & | Females \\
\hline $\begin{array}{lcc}\text { Weight } & \ldots & \ldots \\
\text { Height } & \ldots & \ldots \\
\text { Sitting Height } & \ldots \\
\text { Chest Girth } & \text {. } & \ldots \\
\text { Chest Expansion } & \ldots \\
\text { Pulse Rate } & . . & \ldots \\
\text { Systolic Blood } & \text { Pres- } \\
\text { sure } & \ldots & \ldots \\
\text { Diastolic Blood } & \text { Pres- } \\
\text { sure } & \ldots & \ldots \\
\text { Vital Capacity } & \ldots\end{array}$ & $\begin{aligned} 0.14^{* *} \\
-0.06^{* *} \\
-0.02 \\
0.10^{* *} \\
-0.08^{* *} \\
-0.08^{* *} \\
0.03 \\
0.19^{* *} \\
-0.11^{* *}\end{aligned}$ & $\begin{array}{c}0.02 \\
0.03 \\
0.02 \\
-0.03 \\
-0.08^{*} \\
-0.06 \\
-0.04 \\
0.04 \\
-0.08^{*}\end{array}$ & $\begin{array}{c}0 \cdot 17^{* *} \\
-0.09 \\
0.04 \\
0 \cdot 19^{* *} \\
-0 \cdot 10^{*} \\
-0 \cdot 11^{*} \\
0 \cdot 10^{*} \\
0 \cdot 24^{* *} \\
-0 \cdot 16^{* *}\end{array}$ & $\begin{array}{r}-0.01 \\
0.14 \\
0.09 \\
-0.05 \\
-0.15 \\
-0.12 \\
0.08 \\
0.09 \\
-0.11\end{array}$ \\
\hline
\end{tabular}


for about 1,500 male and 800 female entrants, aged 17 years and over, to the University of Wales in 1949-51. These were also volunteers and again represented about 75 per cent. of all entrants. Men were measured in trousers, women were partially clothed, and none wore shoes.

(3) Kemsley (1951) reported extensive data on weight and height for about 27,500 men and 33,500 women, aged 14 years and over, in Great Britain in 1943. Details were given of the efforts made to obtain subjects in groups which would be reasonably descriptive of the general population. Although the subjects were clothed, adjustment to give nude weights were made before tabulation. To obtain results in our age groups we have interpolated linearly in Kemsley's Tables so that our references to his work are approximate.

(4) Martin (1949) reported data on weight, height, and chest girth for about 90,000 20-year old men of Great Britain who registered for military service during the pre-war months of 1939. These data are probably the most representative of any single age group of a large community yet published, although omissions include men in certain "reserved" occupations, those already in the armed services, and men so infirm that their medical examinations were not completed. All measurements were made without clothing or footwear and the chest was expanded for girth measurement.

(5) Clements and Pickett have given data on height, weight, and chest girth (Clements and Pickett, 1952, 1954a, 1954b) for about 3,700 men aged 18-42 years, who registered for military service in Scotland in 1941. All measurements were made with the subjects clad only in trousers, and reported chest girth was the mean of extreme inspired and expired chest girth measured with the upper edge of a tape touching the nipples and lower angles of the scapulae.

The possible comparisons between our results and those of these five series are shown in Table IV; where necessary, estimates have been converted to metric units and standard errors have been derived from published information. It will be appreciated that the comments which follow are of necessity limited to the age groups for which comparison is possible.

The present data, the Cambridge series of Bailey (1951), and the Welsh series of Grant and Hitchens (1953), are directly comparable in so far as methods of measurement are concerned. On the average, our men were significantly shorter than the Cambridge men by at least $5 \mathrm{~cm}$., but the weights were about the same. Although the mean weights of our women were not significantly different from those of the Welsh University women, our men were significantly heavier by at least $1.9 \mathrm{~kg}$.

The mean weights of our men and women were significantly greater than those reported for the "general population" groups by Kemsley (1951), Martin (1949), and Clements and Pickett (1952). But as the first two reported nude weights, it is reasonable to reduce the relevant differences in Table IV by about $1 \mathrm{~kg}$. for men and about $2 \mathrm{~kg}$. for women. After such correction, our means are still significantly higher, by some 5 to $9 \mathrm{~kg}$. for men and by $5 \mathrm{~kg}$. for women.

TABLE IV

COMPARISON OF PHYSICAL MEASUREMENTS WITH OTHER DATA

\begin{tabular}{|c|c|c|c|c|c|c|c|c|c|}
\hline \multirow{2}{*}{ Sex } & & \multicolumn{4}{|c|}{ Compared Data } & \multirow{2}{*}{$\underset{(y r s)^{*}}{\text { Age Group }}$} & \multicolumn{3}{|c|}{$\begin{array}{c}\text { Difference between Means } \\
\text { (Present Data-Compared Data) }\end{array}$} \\
\hline & & \multicolumn{3}{|c|}{ Authors } & \multirow{2}{*}{$\begin{array}{l}\text { Date } \\
1951\end{array}$} & & Weight (kg.) & Height (cm.) & Chest Girth (cm.) \\
\hline \multirow{5}{*}{ Male } & \multirow{5}{*}{ - } & Bailey .. & $\cdots$ & $\ldots$ & & $\begin{array}{l}18- \\
19- \\
20+\end{array}$ & $\begin{array}{r}0.0 \pm 0.57 \\
-1.0 \pm 0.58 \\
-0.9 \pm 0.41\end{array}$ & $\begin{array}{l}-5 \cdot 7 \pm 0.55 \\
-6 \cdot 1 \pm 0.40 \\
-7.2 \pm 0.36\end{array}$ & \\
\hline & & Grant and & itchens & $\cdots$ & 1953 & $\begin{array}{l}17-18- \\
19- \\
20+\end{array}$ & $\begin{array}{l}2.4 \pm 0.40 \\
2.1 \pm 0.60 \\
2.2 \pm 0.55\end{array}$ & & \\
\hline & & Kemsley & $\cdots$ & . & 1951 & $\begin{array}{l}17- \\
18- \\
19-\end{array}$ & $\begin{array}{r}10.5 \pm 0.44 \\
10.4 \pm 0.36 \\
9.3 \pm 0.50\end{array}$ & $\begin{array}{l}4 \cdot 1 \pm 0 \cdot 40 \\
3 \cdot 2 \pm 0.31 \\
2 \cdot 0 \pm 0.42\end{array}$ & \\
\hline & & Martin . . & $\cdots$ & .. & $1949 * *$ & $\begin{array}{l}20-(a) \\
20-(b)\end{array}$ & $\begin{array}{l}6 \cdot 4 \pm 0 \cdot 40 \\
7 \cdot 3 \pm 0 \cdot 44\end{array}$ & $\begin{array}{r}0 \cdot 3 \pm 0 \cdot 31 \\
-1 \cdot 0 \pm 0 \cdot 32\end{array}$ & $\begin{array}{r}-0.4 \pm 0.26 \\
0.1 \pm 0.27\end{array}$ \\
\hline & & Clements a & Picket & t. & $1952,1954 a, b$ & $17-18-19$ & $6 \cdot 2 \pm 0 \cdot 20$ & $1 \cdot 9 \pm 0.25$ & $2 \cdot 5 \pm 0.20$ \\
\hline \multirow{2}{*}{ Female } & & Grant and & itchens & $\cdots$ & 1953 & $\begin{array}{l}17-18- \\
19- \\
20+\end{array}$ & $\begin{array}{l}0.5 \pm 0.48 \\
0.7 \pm 0.84 \\
1 \cdot 1 \pm 1.17\end{array}$ & & \\
\hline & . & Kemsley & $\cdots$ & $\cdots$ & 1951 & $\begin{array}{l}17- \\
18- \\
19-\end{array}$ & $\begin{array}{l}6.4 \pm 0.55 \\
6 \cdot 4 \pm 0.42 \\
6 \cdot 3 \pm 0.70\end{array}$ & $\begin{array}{l}2.0 \pm 0.42 \\
1.7 \pm 0.32 \\
1.2 \pm 0.47\end{array}$ & \\
\hline
\end{tabular}

- Age $x$-years indicates age $x$ years up to but not including age $(x+1)$ years.

** Compared with age group (a) 19- and (b) $20+$ years of present series. 
Our undergraduates were significantly taller, on average, than the subjects of comparable age and sex in the series reported by Kemsley (1951) and Clements and Pickett (1954a). The difference varied from about 1 to $4 \mathrm{~cm}$. The mean chest girth of our men was also significantly greater than that reported by Clements and Pickett (1954b), but part of this might be attributed to different methods of measurement. Although it was impossible to make a direct comparison of comparable age groups with the series of Martin (1949), Table IV suggests that the means of height and chest girth of our series were very similar to those reported by him; as chest girth in his series relates to expanded chest it is reasonable to conclude that our men are in fact some $4 \mathrm{~cm}$. bigger in average chest girth.

The incompleteness of Table IV and the lack of data at identical age groups makes any attempt to sum up these comparisons difficult. But for the heights of Martin's men, it would be reasonable to conclude that our men and women were taller and heavier, and that the men had a greater chest girth, on the average, than the general population groups at ages for which comparison could be made. On the other hand our men were shorter than those at Cambridge and heavier than those at the University of Wales.

\section{Clinical Measurements}

General.-Table $\mathrm{V}$ gives estimates of mean pulse rate, systolic and diastolic blood pressure, and vital capacity. The relevant correlation coefficients are given in Table III.

Pulse Rate.-There were significant differences between the mean pulse rates of the four age groups
(Appendix Serials 14 and 15), but for like age groups the sex differences were negligible (Table V). The age differences were largely due to low means in the oldest age group, although over the whole age range there was a small but significant negative correlation between age and pulse rate for men (Table III). The effect of this association was negligible; if linear regression is assumed, an average difference of $-0.2 \pm 0.05$ beats per minute per increase of one year in age might be expected.

For the male undergraduates at Cambridge, to which we have already referred, Bailey (1951) found a mean pulse rate of $70.3 \pm 0.3$ beats per minute, which is significantly, and quite considerably slower, than the mean in any age group of the present series. Bailey found no association with age and for all ages combined his mean was $8 \cdot 1 \pm 0 \cdot 4$ beats per minute slower than ours. His observations were also more widely dispersed than ours; the standard deviations were 11.4 and 8.7 beats per minute, a significant difference of $2 \cdot 7 \pm 0 \cdot 3$ beats per minute.

Blood Pressure.-The mean systolic pressure in men was significantly greater than that in women at each age group (Table V). Among males there were no significant differences in mean systolic pressure between ages. A low mean in the oldest age group was largely responsible for the female means not being similarly homogeneous (Appendix Serials 16 and 17), and the lack of significant correlation with age (Table III) among females supported this observation. It is of interest to note a small significant correlation of $r=0.10$ for males aged 20 and over, as this, coupled with the rather older mean age in this group of men than of women,

TABle V

CLINICAL MEASUREMENTS

\begin{tabular}{|c|c|c|c|c|c|c|c|}
\hline \multirow{2}{*}{ Measurement } & \multirow{2}{*}{ Sex } & \multicolumn{5}{|c|}{ Mean Measurement for Stated Age Group (yrs) } & \multirow{2}{*}{$\begin{array}{c}\text { Standard } \\
\text { Deviation } \\
\text { Within Age } \\
\text { Groups } \\
\end{array}$} \\
\hline & & $17-$ & 18- & 19 & $20+$ & Total & \\
\hline \multirow{2}{*}{$\begin{array}{c}\text { Pulse Rate (beats } \\
\text { per minute) }\end{array}$} & $\begin{array}{l}\text { Male } \\
\text { Female }\end{array}$ & $\begin{array}{l}78 \cdot 5 \\
77 \cdot 9\end{array}$ & $\begin{array}{l}78 \cdot 8 \\
79 \cdot 4\end{array}$ & $\begin{array}{l}78 \cdot 8 \\
79 \cdot 8\end{array}$ & $\begin{array}{l}77 \cdot 2 \\
76 \cdot 7\end{array}$ & $\begin{array}{l}78 \cdot 4 \\
78 \cdot 9\end{array}$ & $\begin{array}{l}8 \cdot 69 \\
8 \cdot 55 \\
\end{array}$ \\
\hline & Difference (M-F) & $0.6 \pm 0.84$ & $-0.6 \pm 0.53$ & $-1.0 \pm 0.88$ & $0.5 \pm 1.04$ & $-0 \cdot 5 \pm 0.37$ & \\
\hline \multirow{2}{*}{ 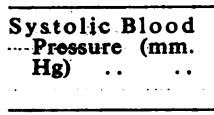 } & $\begin{array}{lll}\text { Male } & \cdots & \mathbf{M} \\
\text { Female } & \ldots & \mathbf{F} \\
\end{array}$ & $\begin{array}{l}129 \cdot 3 \\
123 \cdot 9\end{array}$ & $\begin{array}{l}130 \cdot 0 \\
125 \cdot 8 \\
\end{array}$ & $\begin{array}{l}130 \cdot 6 \\
125 \cdot 7\end{array}$ & $\begin{array}{l}129 \cdot 9 \\
122 \cdot 1 \\
\end{array}$ & $\begin{array}{l}130 \cdot 0 \\
125: 0 \\
\end{array}$ & $\begin{array}{l}10 \cdot 87 \\
10 \cdot 14\end{array}$ \\
\hline & Difference (M-F) & $5 \cdot 4 \pm 1 \cdot 02$ & $4 \cdot 2 \pm 0.64$ & $4.9 \pm 1.05$ & $7 \cdot 8 \pm 1 \cdot 24$ & $5 \cdot 0 \pm 0 \cdot 44$ & ……........... \\
\hline \multirow{2}{*}{ 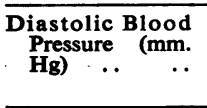 } & $\begin{array}{l}\text { Male } \\
\text { Female }\end{array}$ & $\begin{array}{l}70 \cdot 1 \\
69 \cdot 9 \\
\end{array}$ & $\begin{array}{l}70 \cdot 9 \\
71 \cdot 1 \\
\end{array}$ & $\begin{array}{l}71 \cdot 2 \\
72 \cdot 0 \\
\end{array}$ & \begin{tabular}{|l|}
$73 \cdot 7$ \\
$71 \cdot 0$ \\
\end{tabular} & $\begin{array}{l}71 \cdot 4 \\
71 \cdot 0 \\
\end{array}$ & $\begin{array}{r}8 \cdot 24 \\
8 \cdot 40 \\
\end{array}$ \\
\hline & Difference (M-F) & $0.2 \pm 0.82$ & $-0.2 \pm 0.51$ & $-0.8 \pm 0.85$ & $2 \cdot 7 \pm 1 \cdot 01$ & $0.4 \pm 0.36$ & \\
\hline \multirow{2}{*}{$\begin{array}{l}\text { Vital Capacity } \\
\text { (litres of air) } .\end{array}$} & $\begin{array}{l}\text { Male } \\
\text { Female }\end{array}$ & $\begin{array}{l}3 \cdot 97 \\
2 \cdot 72\end{array}$ & $\begin{array}{l}3.96 \\
2.73 \\
\end{array}$ & $\begin{array}{l}3.96 \\
2.71 \\
\end{array}$ & $\begin{array}{l}3 \cdot 83 \\
2 \cdot 59 \\
\end{array}$ & $\begin{array}{l}3.93 \\
2 \cdot 71 \\
\end{array}$ & $\begin{array}{l}0.69 \\
0.55 \\
\end{array}$ \\
\hline & Difference (M-F) & $1 \cdot 25 \pm 0.06$ & $1 \cdot 23 \pm 0.04$ & $1 \cdot 25 \pm 0.06$ & $1 \cdot 24 \pm 0.07$ & $1.22 \pm 0.02$ & $\therefore$ \\
\hline
\end{tabular}


might account for the sex difference in mean pressure being somewhat greater in that age group than in others.

Mean diastolic pressure in men increased significantly from the youngest to oldest age group but there were no significant differences between age groups of women (Appendix Serials 18 and 19). The correlation coefficients of Table III support these observations. Over the whole age range for males, $r=0 \cdot 19$, and for the age group 20 and over, $r=0 \cdot 24$. Between the two sexes the means were significantly different only in the oldest age group where the males had the higher mean pressure; this finding again might be partially due to the age association in males coupled with relatively more older men than women in that age group.

In the Cambridge series of male undergraduates Bailey (1951), no significant association of age with blood pressure was detected over the age range 18 to 22 years. His mean systolic pressure, 129.7 \pm $0.3 \mathrm{~mm}$. $\mathrm{Hg}$, was not significantly different from that of our men, $130.0 \pm 0.25$, a difference of $0.3 \pm 0.39 \mathrm{~mm}$. Hg. His mean diastolic pressure, $79.2 \pm 0.2 \mathrm{~mm}$. $\mathrm{Hg}$, however, was much higher than that found in any of our age groups. The difference between Bailey's mean and ours at all ages was $7.8 \pm 0.3 \mathrm{~mm}$. $\mathrm{Hg}$, and that between Bailey's mean and oưr maximum in age group 20 years and over was $5.5 \pm 0.5 \mathrm{~mm}$. $\mathrm{Hg}$.

Two recent-genetical studies on arterial blood pressure have resulted in data being available for samples of the general population:

(1) Hamilton, Pickering, Roberts, and Sowry (1954) obtained arterial pressures from a sample of about
1,200 male and 800 female hospital out-patients aged 10 to 84 years. Patients were attending clinics where diseases affecting arterial pressure were unlikely to be seen.

(2) Miall and Oldham (1955) made measurements on a representative sample of the general population of a South Wales mining valley. The sample consisted of 137 males and 113 females aged 5 and over.

Both sets of workers used cubic equations to describe the relationships between pressure and age and, by substituting appropriate ages for each of our age groups in these equations, we have derived the "expected" average pressures shown in Table VI and compared these with our observed means.

The mean pressures for the South Wales sample were higher than the hospital sample at most age groups and Miall and Oldham felt that this was largely due to the methods of selection, although differences in arm circumferences and, possibly, in occupations, may also have had an influence. Nevertheless, at the ages for which comparison can be made, our systolic pressures were generally higher than both the South Wales and the hospital series. On the other hand, our diastolic pressures were very similar to the hospital series and consequently lower than the South Wales sample. It will be remembered that Bailey's means for the Cambridge men were similar to ours for systolic pressure; his diastolic means, however, more closely resemble those of South Wales.

Thus systolic pressures in both university series might be considered as unreasonably high. It might be argued, in many cases, that the strain of the young

TABLE VI

OBSERVED MEANS OF ARTERIAL PRESSURE (mm. Hg) COMPARED WITH THOSE EXPECTED FROM OTHER DATA

\begin{tabular}{|c|c|c|c|c|c|c|}
\hline \multirow{2}{*}{ Age (yrs) } & \multirow{2}{*}{\multicolumn{2}{|c|}{ Observed or Expected * }} & \multicolumn{2}{|c|}{ Mean Systolic Pressure } & \multicolumn{2}{|c|}{ Mean Diastolic Pressure } \\
\hline & & & Males & Females & Male & Females \\
\hline $17 \cdot 5$ & $\begin{array}{l}\text { Observed } \\
\text { Expected (a) } \\
\text { (b) }\end{array}$ & $\begin{array}{l}\cdots \\
\cdots\end{array}$ & $\begin{array}{l}129 \cdot 3 \pm 0.62 \\
115 \cdot 2 \\
121 \cdot 5\end{array}$ & $\begin{array}{l}123 \cdot 9 \pm 0.81 \\
117 \cdot 0 \\
115 \cdot 3\end{array}$ & $\begin{array}{l}70 \cdot 1 \pm 0.47 \\
69 \cdot 1 \\
77.9\end{array}$ & $\begin{array}{l}69.9 \\
70.3 \\
73.6\end{array}$ \\
\hline $18 \cdot 5$ & $\begin{array}{l}\text { Observed } \\
\text { Expected (a) } \\
\text { (b) }\end{array}$ & $\begin{array}{l}\cdots \\
\cdots\end{array}$ & $\begin{array}{l}130 \cdot 0 \pm 0 \cdot 37 \\
115 \cdot 3 \\
122 \cdot 6\end{array}$ & $\begin{array}{l}125 \cdot 8 \pm 0 \cdot 52 \\
117 \cdot 1 \\
116: 0\end{array}$ & $\begin{array}{l}70 \cdot 9 \pm 0.28 \\
69 \cdot 5 \\
78 \cdot 4\end{array}$ & $\begin{array}{l}71 \cdot 1 \pm 0.43 \\
70.6 \\
73.9\end{array}$ \\
\hline $19 \cdot 5$ & $\begin{array}{l}\text { Observed }(\dot{0}) \\
\text { Expected }(a)\end{array}$ & $\begin{array}{l}\cdots \\
\cdots\end{array}$ & $\begin{array}{l}130 \cdot 6 \pm 0.55 \\
115 \cdot 4 \\
123 \cdot 5\end{array}$ & $\begin{array}{l}125 \cdot 7 \pm 0.90 \\
117 \cdot 2 \\
116 \cdot 8\end{array}$ & $\begin{array}{l}71 \cdot 2 \pm 0 \cdot 42 \\
70 \cdot 0 \\
78 \cdot 9\end{array}$ & $\begin{array}{l}72 \cdot 0 \\
71 \cdot 0 \\
74 \cdot 3\end{array}$ \\
\hline $23 \cdot 5$ & $\begin{array}{l}\text { Observed } \\
\text { Expected }(a)\end{array}$ & $\begin{array}{l}\cdots \\
\cdots \\
\cdots\end{array}$ & & $\begin{array}{l}122 \cdot 1 \pm 1 \cdot 12 \\
118 \cdot 2 \\
119 \cdot 8\end{array}$ & & $\begin{array}{l}71 \cdot 0 \pm 0.93 \\
72 \cdot 6 \\
75 \cdot 8\end{array}$ \\
\hline $24 \cdot 3$ & $\begin{array}{l}\text { Observed } \\
\text { Expected }(a) \\
(b)\end{array}$ & $\begin{array}{l}\ddot{ } \\
\ddot{*}\end{array}$ & $\begin{array}{l}129 \cdot 9 \pm 0.54 \\
116 \cdot 2 \\
127 \cdot 3\end{array}$ & & $\begin{array}{l}73.7 \pm 0.41 \\
71.9 \\
80.9\end{array}$ & \\
\hline
\end{tabular}

* Expected (a) based on data of Hamilton and others (1954).

(b) based on data of Miall and Oldham (1955). 
students' first rigorous medical examination tended to increase the pressure, even when care was taken to give reasonable resting time. Clearly more work is required in this field, in the shape of repeated estimates on the same students over a period of time. In this context it is of interest to note that when the blood pressures of 35 third-year male students were taken in 1956, as part of the preclinical examination given to all medical undergraduates, their systolic pressures were, in all but five cases, significantly lower than at their initial examination, 2 or 3 years earlier. The average decrease in systolic pressure was $5.9 \mathrm{~mm}$. $\mathrm{Hg}$ $(t=3.38 ; D F=34 ; 0.01>P>0.001)$. Corresponding diastolic pressures were very similar, the average difference being a negligible increase of $0.7 \mathrm{~mm}$. Hg $(t=0.47 ; D F=34 ; 0.70>P>$ $0 \cdot 60)$.

Vital Capacity.-The mean vital capacity of the men, but not of the women, was significantly different between age groups (Appendix Serials 20 and 21). Vital capacity decreased, on the average, as age advanced (Table V), and the correlation coefficients (Table III) suggest that this association with age became stronger after age 20. At each age group the means for males were significantly much greater by about $1 \cdot 25$ litres of air than those for females.

Whitfield, Waterhouse, and Arnott (1950) demonstrated the influence of various physical measurements on vital capacity and Garrad (1949) underlined the practical difficulties of comparing vital capacity estimates between different groups of individuals. Therefore no attempt is made here to compare the crude means with those of other workers.

\section{VISION AND HEARING}

Visual Acuity.-Table VII shows the percentage distribution of each sex, according to visual acuity.

TABLE VII

VISUAL ACUITY

\begin{tabular}{|c|c|c|c|}
\hline & \multirow[t]{2}{*}{ Visual Acuity } & \multicolumn{2}{|c|}{$\begin{array}{l}\text { Percentage } \\
\text { Distribution }\end{array}$} \\
\hline & & Males & Females \\
\hline $6 / 6$ and Better & $\begin{array}{l}\text { In both eyes } \ldots \\
\text { In one eye, other worse }\end{array}$ & $\begin{array}{l}59 \cdot 46 \\
12 \cdot 51\end{array}$ & $\begin{array}{l}58 \cdot 40 \\
11 \cdot 87\end{array}$ \\
\hline $6 / 9$ or $6 / 12$ & $\begin{array}{l}\text { In both eyes } \ldots \\
\text { In one eye, other worse }\end{array}$ & $\begin{array}{l}6 \cdot 26 \\
5 \cdot 65\end{array}$ & $\begin{array}{l}5 \cdot 73 \\
4 \cdot 80\end{array}$ \\
\hline $6 / 18$ to $6 / 36$ & $\begin{array}{l}\text { In both eyes } \ldots \\
\text { In one eye, other worse }\end{array}$ & $\begin{array}{l}5 \cdot 24 \\
3 \cdot 00\end{array}$ & $\begin{array}{l}4 \cdot 53 \\
4 \cdot 53\end{array}$ \\
\hline $6 / 60$ or Less & In both eyes & $7 \cdot 88$ & $10 \cdot 13$ \\
\hline Total & $\ldots$ & $100 \cdot 0$ & $100 \cdot 0$ \\
\hline
\end{tabular}

$\chi^{2}$ (on absolute numbers) $=8.74 ; D F=6 ; 0.2>P>0.10$
Preliminary examination of similar distributions for the separate age groups showed no significant differences between age groups (for males $\chi^{2}=28.55 ; D F=18 ; 0.10>P>0.05$, and for females, treating 19 years and over as one group, $\chi^{2}=15.99 ; D F=12 ; 0.20>P>0 \cdot 10$ ).

As Table VII shows, the sex differences were negligible, and just under 60 per cent. of the students had vision of $6 / 6$ or better in both eyes. This proportion was somewhat below that found by Martin (1949) in his young adult males, and that reported by Bailey (1951) for the Cambridge male undergraduates. Table VIII compares the complete distributions from these two series with our male data; the high proportion of undergraduates of both universities with vision of $6 / 60$ or less in both eyes is worth noting.

TABLE VIII

COMPARISON OF VISUAL ACUITY WITH OTHER DATA (Males only)

\begin{tabular}{|c|c|c|c|c|}
\hline \multirow{2}{*}{\multicolumn{2}{|c|}{ Visual Acuity }} & \multicolumn{3}{|c|}{ Percentage Distributions } \\
\hline & & $\begin{array}{c}\text { Present } \\
\text { Data }\end{array}$ & $\underset{\text { (1949) }}{\text { Martin }}$ & $\begin{array}{l}\text { Bailey } \\
\text { (1951) }\end{array}$ \\
\hline 6/6 and Better & $\begin{array}{l}\text { In both eyes } \\
\text { In one eye, } \\
\text { other worse }\end{array}$ & $\begin{array}{c}59 \cdot 46 \\
12 \cdot 51\end{array}$ & $\begin{array}{l}65 \cdot 9 \\
13 \cdot 3\end{array}$ & $\begin{array}{r}62 \cdot 1 \\
11 \cdot 9\end{array}$ \\
\hline $6 / 9$ or $6 / 12$ & $\begin{array}{l}\text { In both eyes } \\
\text { In one eye, } \\
\text { other worse }\end{array}$ & $\begin{array}{l}6 \cdot 26 \\
5 \cdot 65\end{array}$ & $\begin{array}{l}7 \cdot 6 \\
3 \cdot 8\end{array}$ & $\begin{array}{l}3 \cdot 4 \\
4 \cdot 4\end{array}$ \\
\hline $6 / 18$ to $6 / 36$ & $\begin{array}{l}\text { In both eyes } \\
\text { In one eye, } \\
\text { other worse }\end{array}$ & $\begin{array}{l}5 \cdot 24 \\
3 \cdot 00\end{array}$ & $\begin{array}{l}4 \cdot 6 \\
2 \cdot 2\end{array}$ & $\begin{array}{l}7 \cdot 5 \\
2 \cdot 6\end{array}$ \\
\hline $6 / 60$ or Less & In both eyes & $7 \cdot 88$ & $2 \cdot 6$ & $8 \cdot 1$ \\
\hline Total $\ldots$ & $\ldots$ & $100 \cdot 0$ & $100 \cdot 0$ & $100 \cdot 0$ \\
\hline \multicolumn{2}{|c|}{ No. on which Percentages are } & 1,966 & 90,913 & 1,477 \\
\hline
\end{tabular}

$\chi^{2}$ on absolute numbers:

Present data $v$ Martin's data: $\chi^{2}=240.92 ; D F=6 ; P<0.001$

Present data $v$ Bailey's data: $\chi^{2}=25 \cdot 24 ; D F=6 ; P<0.001$

Sorsby, Benjamin, and Yudkin (1955) reported on the visual acuity of 501 men employed by the Post Office. In the age group 21 to 24 years, $68 \cdot 6$ per cent. had $6 / 6$ or better vision in both eyes; this was again higher than our series, and although there was some slight selection of the postal workers due to minimum eye standards required on recruitment, it seems unlikely that it could account for the whole difference.

Colour Vision.-Of the 1,966 men examined, 136 (6.9 per cent.) were found to be colour blind. The 136 abnormal findings were varying degrees of red-green colour blindness. The importance of detecting such defects early in university life cannot 
be over-emphasized. For some potential science students, the handicap is such that a change in their proposed course of study is often advisable.

A similar proportion (5.8 per cent.) was detected by Sorsby and others (1955) in their post-office workers (difference $=1 \cdot 1 \pm 1 \cdot 2$ per cent.), but Betenson (1955), in some 6,000 school medical inspections in Brecknock, found only $4 \cdot 1$ per cent. of the boys to be colour blind; this is significantly below our figure by $2.8 \pm 0.6$ per cent.

Hearing.-Table IX shows the proportions of students who had defective hearing. In all, this amounted to $7 \cdot 17$ per cent. of the men and 5.47 per cent. of the women. As the $\chi^{2}$ values show, age had no material influence upon this proportion among women, but it had among men, because in each age group up to age 20 years 6 per cent. were defective, while at age 20 and over the proportion was 11 per cent. Thus although in total the sex difference was unimportant (1.70 $\pm 1 \cdot 01$ per cent.), at age $20+$ years it was significant and fairly large $(6 \cdot 26 \pm 2 \cdot 85$ per cent.).

TABLE IX

HEARING

\begin{tabular}{|c|c|c|c|}
\hline \multirow{2}{*}{$\begin{array}{c}\text { Age Group } \\
\text { (yrs) }\end{array}$} & \multicolumn{2}{|c|}{$\begin{array}{l}\text { Percentage with } \\
\text { Defective Hearing }\end{array}$} & \multirow{2}{*}{$\begin{array}{l}\text { Percentage Difference } \\
\text { (Males-Females) } \\
\pm \text { Standard Error }\end{array}$} \\
\hline & Males & Females & \\
\hline $\begin{array}{l}17- \\
18- \\
19- \\
20+\end{array}$ & $\begin{array}{r}6 \cdot 11 \\
6 \cdot 03 \\
6 \cdot 44 \\
11 \cdot 14\end{array}$ & $\begin{array}{l}6 \cdot 41 \\
4 \cdot 95 \\
6 \cdot 25 \\
4 \cdot 88\end{array}$ & $\begin{array}{r}-0.30 \pm 2.39 \\
1.08 \pm 1.37 \\
0.19 \pm 2.48 \\
6.26 \pm 2.85\end{array}$ \\
\hline Total & $7 \cdot 17$ & $5 \cdot 47$ & $1 \cdot 70 \pm 1 \cdot 01$ \\
\hline
\end{tabular}

On absolute numbers test for association with age:

Males $x^{2}=12.09 ; D F=3 ; 0.01>P>0.001$ Females $\chi^{2}=0.49 ; D F=2 ; 0.80>P>0.7$ (age groups 19- and
$20+$ combined).

\section{SUMMARY}

(1) At the Queen's University of Belfast, in the 5 years 1949-54, 1,966 male and 750 female undergraduates were medically examined in their first year at the University.

(2) Average measurements are tabulated by age group and sex for weight, height, sitting height, chest girth, and chest expansion (Table II), and for pulse rate, systolic and diastolic blood pressure, and vital capacity (Table V).

(3) Distribution of the students by standard of visual acuity (Table VII) and hearing (Table IX) is also tabulated and colour vision is mentioned in the text.

(4) At the age range concerned, the male measurements of weight, height, chest girth, chest expansion, pulse rate, diastolic blood pressure, and vital capacity were all slightly associated with age; as age increased, weight, chest girth, and diastolic pressure increased while the others decreased. Above age 20 there was some indication of a small positive correlation between age and male systolic pressure.

(5) With the numbers available, few significant associations with age were observed in the female measurements. However, pulse rate and systolic blood pressure both tended to be significantly low at age 20 and over compared with younger women, and the correlations suggested a slight decrease in chest expansion and vital capacity with increasing age.

(6) On the average all the physical measurements, systolic pressure, and vital capacity were higher for men than for women of the same age.

(7) No sex or age differences were apparent in the distribution of the students by visual standards. Of all students about 60 per cent. had $6 / 6$ or better vision in both eyes and about 8 per cent. had 6/60 or worse. Of the men about 7 per cent. were redgreen colour blind.

(8) The percentage of men with defective hearing increased from just over 6 per cent. below age 20 to just over 11 per cent. above that age. This was not a feature of the tests on women, of whom 5.5 per cent. had defective hearing.

(9) The possible comparisons with other data are limited, but such comparisons do raise the question of the usefulness of including blood pressure readings in such examinations unless such readings are confirmed at follow-up examinations. Our systolic pressures were higher than those expected from the best standards at present available, but we have some evidence to suggest that part of this difference would have disappeared had the students been again examined at a later date.

We are particularly indebted to Sister P. Rock who assisted at the examinations, and wish to thank Miss I. Boyce, of the Student Health Department, Miss D. B. I. Wood, Mr. J. S. Crockett, and the late Miss Margaret Moran of the Department of Social and Preventive Medicine, who also helped us considerably. 


\section{REFERENCES}

Bailey, N. T. J. (1951). J. Hyg. (Camb.), 49, 81.

Betenson, W. F. W. (1955). Med. Offr., 94, 169.

Cardiac Society of Great Britain and Ireland and the American Heart Association (1939). Brit. Heart J., 1, 261.

Clements, E. M. B., and Pickett, K. G. (1952). British Journal of Preventive and Social Medicine, 6, 245. 8, 99. (1954a). British Journal of Social and Preventive Medicine,

(1954b). Ibid. 8, 108

Garrad, J. (1949). Brit. J. industr. Med., 6, 221.

Grant, G., and Hitchens, R. A. N. (1953). British Journal of Social and Preventive Medicine, 7, 60 .
Hamilton, M., Pickering, G. W., Fraser Roberts, J. A., and Sowry, G. S. C. (1954). Clin. Sci., 13, 11.

Ishihara, S. (1943). "Tests for Colour-Blindness", 9th ed. Lewis, London.

Kemsley, W. F. F. (1950). Ann. Eugen. (Camb.), 15, 161.

Martin, W. J. (1949). "The Physique of Young Adult Males." Memo. med. Res. Coun., Lond., No. 20. H.M.S.O., London.

Miall, W. E., and Oldham, P. D. (1955). Clin. Sci., 14, 459.

Sorsby, A., Benjamin, B., and Yudkin, J. (1955). British Journal of Social and Preventive Medicine, 9, 1.

Whitfield, A. G. W., Waterhouse, J. A. H., and Arnott, W. M. (1950). British Journal of Social and Preventive Medicine, 4, 113.

APPENDIX TABLE

ANALYSIS OF VARIANCE

\begin{tabular}{|c|c|c|c|c|c|c|}
\hline & . & $\begin{array}{l}\text { APPE } \\
\text { ANALY }\end{array}$ & $\begin{array}{l}\text { DIX TABLE } \\
\text { OF VARIANCE }\end{array}$ & & & \\
\hline Serial No. & Variable & Sex & Source of Variation & Sum of Squares & $D F$ & Mean Square \\
\hline \multirow{3}{*}{1} & \multirow{9}{*}{ Age (yrs) } & \multirow{3}{*}{ Male } & $\begin{array}{l}\text { Between Yrs of Entry } \\
\text { Within Yrs of Entry }\end{array}$ & $\begin{array}{r}110 \cdot 67 \\
25,005 \cdot 40 \\
\end{array}$ & $\begin{array}{r}4 \\
1,961 \\
\end{array}$ & $\begin{array}{r}27 \cdot 67 \\
.12 \cdot 75 \\
\end{array}$ \\
\hline & & & Total .. $\quad . . \quad \ldots$ & $25,116 \cdot 07$ & 1,965 & \\
\hline & & & \multicolumn{4}{|c|}{$F=2 \cdot 17 ; n_{1}=4, n_{2}=1,961 ; 0 \cdot 10>P>0.05$} \\
\hline \multirow{3}{*}{2} & & \multirow{3}{*}{ Female } & $\begin{array}{l}\text { Between Yrs of Entry } \\
\text { Within Yrs of Entry }\end{array}$ & $\begin{array}{r}30 \cdot 82 \\
4,695 \cdot 60\end{array}$ & $\begin{array}{r}4 \\
745\end{array}$ & $\begin{array}{l}7 \cdot 71 \\
6 \cdot 30\end{array}$ \\
\hline & & & $\begin{array}{lll}\text { Total } \ldots & \ldots & \ldots \\
\end{array}$ & $4,726 \cdot 42$ & 749 & \\
\hline & & & \multicolumn{4}{|c|}{$F=1 \cdot 22 ; n_{1}=4, n_{2}=745 ; P>0.20$} \\
\hline \multirow{3}{*}{3} & & \multirow{3}{*}{ Both } & \multirow{2}{*}{ 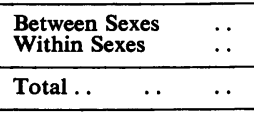 } & $\begin{array}{r}325 \cdot 45 \\
29,842 \cdot 49 \\
\end{array}$ & $\begin{array}{r}1 \\
2,714 \\
\end{array}$ & $\begin{array}{r}325 \cdot 45 \\
10 \cdot 97 \\
\end{array}$ \\
\hline & & & & $30,167 \cdot 94$ & 2,715 & \\
\hline & & & \multicolumn{3}{|c|}{$F=29.68 ; n_{1}=1, n_{2}=2,714 ; P<0.001$} & \\
\hline \multirow{3}{*}{4} & \multirow{6}{*}{ Weight (kg.) } & \multirow{3}{*}{ Male } & $\begin{array}{l}\text { Between Age Groups } \\
\text { Within Age Groups } \\
\end{array}$ & $\begin{array}{r}1,750 \cdot 05 \\
125,241 \cdot 85 \\
\end{array}$ & 1,962 & $\begin{array}{r}583 \cdot 35 \\
63 \cdot 83 \\
\end{array}$ \\
\hline & & & $\begin{array}{lll}\text { Total } \ldots & \ldots & \ldots \\
\end{array}$ & $126,991 \cdot 90$ & 1,965 & \\
\hline & & & \multirow{2}{*}{$\begin{array}{l}F=9 \cdot 14 ; n_{1}=3, n_{2} \\
\text { Between Age Groups } \\
\text { Within Age Groups }\end{array}$} & 1,$962 ; P<0.001$ & & \\
\hline \multirow{3}{*}{5} & & \multirow{3}{*}{ Female } & & $\begin{array}{r}84 \cdot 76 \\
41,531 \cdot 68 \\
\end{array}$ & $\begin{array}{r}3 \\
746 \\
\end{array}$ & $\begin{array}{l}28 \cdot 25 \\
55 \cdot 67 \\
\end{array}$ \\
\hline & & & $\begin{array}{lll}\text { Total } \ldots & \ldots & \ldots \\
\end{array}$ & $41,616 \cdot 44$ & 749 & \\
\hline & & & \multicolumn{4}{|c|}{$F=1.97 ; n_{1}=746, n_{2}=3 ; P>0.20$} \\
\hline \multirow{3}{*}{6} & \multirow{6}{*}{ Height (cm.) } & \multirow{3}{*}{ Male } & $\begin{array}{l}\text { Between Age Groups } \\
\text { Within Age Groups }\end{array}$ & $\begin{array}{r}781 \cdot 96 \\
71,968 \cdot 23 \\
\end{array}$ & $\begin{array}{r}3 \\
1,962 \\
\end{array}$ & $\begin{array}{r}260 \cdot 65 \\
36 \cdot 68 \\
\end{array}$ \\
\hline & & & $\begin{array}{lll}\text { Total } \ldots & \ldots & \ldots \\
\end{array}$ & $72,750 \cdot 19$ & 1,965 & \\
\hline & & & $F=7 \cdot 11 ; n_{1}=3, n_{2}=$ & 1,$962 ; P<0.001$ & & \\
\hline \multirow{3}{*}{7} & & \multirow{3}{*}{ Female } & $\begin{array}{l}\text { Between Age Groups } \\
\text { Within Age Groups }\end{array}$ & $\begin{array}{r}16 \cdot 78 \\
22,197 \cdot 84 \\
\end{array}$ & $\begin{array}{r}3 \\
746 \\
\end{array}$ & $\begin{array}{r}5 \cdot 59 \\
29 \cdot 76 \\
\end{array}$ \\
\hline & & & $\begin{array}{lll}\text { Total } \ldots & \ldots & \because \\
\end{array}$ & $22,214 \cdot 62$ & 749 & \\
\hline & & & $F=5 \cdot 32 ; n_{1}=746, n_{1}$ & $=3: 0 \cdot 10>P>$ & & \\
\hline \multirow{3}{*}{8} & \multirow{6}{*}{ Sitting Height (cm.) } & \multirow{3}{*}{ Male } & $\begin{array}{l}\text { Between Age Groups } \\
\text { Within Age Groups } \\
\end{array}$ & $\begin{array}{r}92 \cdot 15 \\
28,285 \cdot 05 \\
\end{array}$ & $\begin{array}{r}3 \\
1,962 \\
\end{array}$ & $\begin{array}{l}30 \cdot 72 \\
14 \cdot 42 \\
\end{array}$ \\
\hline & & & $\begin{array}{lll}\text { Total } \ldots & \ldots & \ldots \\
\end{array}$ & $28,377 \cdot 20$ & 1,965 & \\
\hline & & & $F=2 \cdot 13 ; n_{1}=3, n_{2}=$ & 1,$962 ; 0 \cdot 10>P>$ & .05 & \\
\hline \multirow{3}{*}{9} & & \multirow{3}{*}{ Female } & $\begin{array}{l}\text { Between Age Groups } \\
\text { Within Age Groups }\end{array}$ & $\begin{array}{r}21 \cdot 46 \\
9,601 \cdot 29 \\
\end{array}$ & $\begin{array}{r}3 \\
746 \\
\end{array}$ & $\begin{array}{r}7 \cdot 15 \\
12 \cdot 87 \\
\end{array}$ \\
\hline & & & $\begin{array}{lll}\text { Total } \ldots & \ldots & \ldots \\
\end{array}$ & $9,622 \cdot 75$ & 749 & \\
\hline & & & $F=1 \cdot 80 ; n_{1}=746, n_{2}$ & $=3: P>0.20$ & & \\
\hline
\end{tabular}




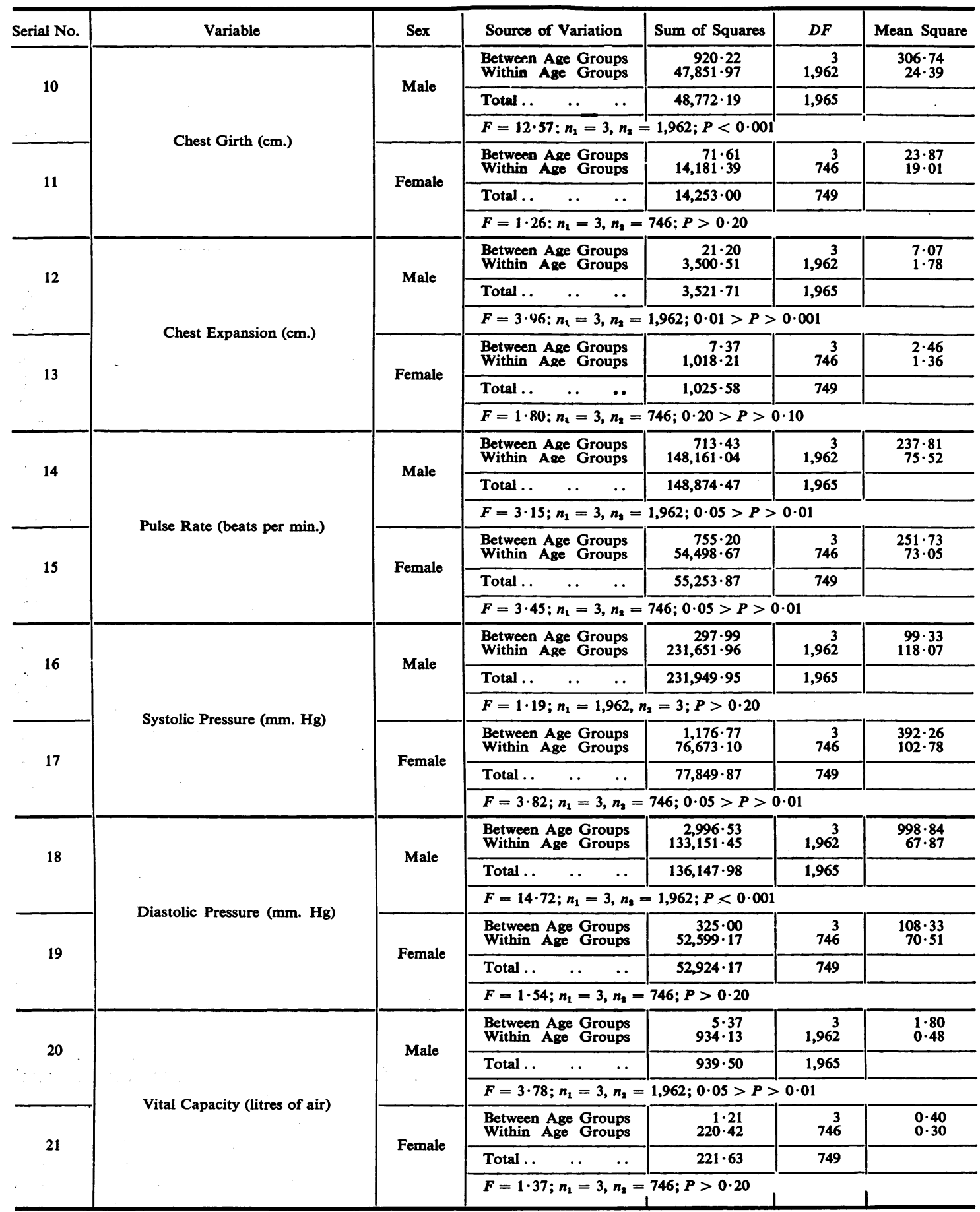

